\title{
First record of the landsnail Ferussacia folliculum (Schröter, 1784) in Belgium (Mollusca: Gastropoda: Ferussaciidae)
}

\section{Rose Sablon ${ }^{1, *}$, Marc Hansen ${ }^{1,2} \&$ Thierry Backeljau ${ }^{1,3}$}

${ }^{1}$ Royal Belgian Institute of Natural Sciences, Vautierstraat 29, B-1000 Brussels, Belgium.

${ }^{2}$ Royal Belgian Society for Conchology, Kabienstraat 1 bus D2, B-2290 Vorselaar, Belgium.

${ }^{3}$ Evolutionary Ecology Group, University of Antwerp, Universiteitsplein 1, B-2610 Antwerp, Belgium

${ }^{*}$ Corresponding author: rose.sablon@naturalsciences.be

KEYWORDS. Mollusca, Ferussacia folliculum, alien species, Belgium.

Sablon R., Hansen M. \& Backeljau T. 2017. First record of the landsnail Ferussacia folliculum (Schröter, 1784) in Belgium (Mollusca: Gastropoda: Ferussaciidae). Belgian Journal of Zoology 147 (1): 77-80. https://doi. org/10.26496/bjz.2017.6

Ferussacia folliculum (Schröter, 1784), currently also known as Ferussacia folliculus or Ferussacia follicula, two very common, but incorrect, spellings (1), is a small herbivorous landsnail with a variable fusiform-ovate, very glossy yellowish to pale brown shell. It has 5-6 almost flat whorls and adult shells measure $6-9 \times 2.5-3.5 \mathrm{~mm}$. The apertural margin is sharp and connected, at the parietal side, by a transparent callus. The animal is pale with a greenish hue. It has a dark head with rather long upper tentacles. It thrives in natural and disturbed habitats, under stones, litter, and in moist grassy places;

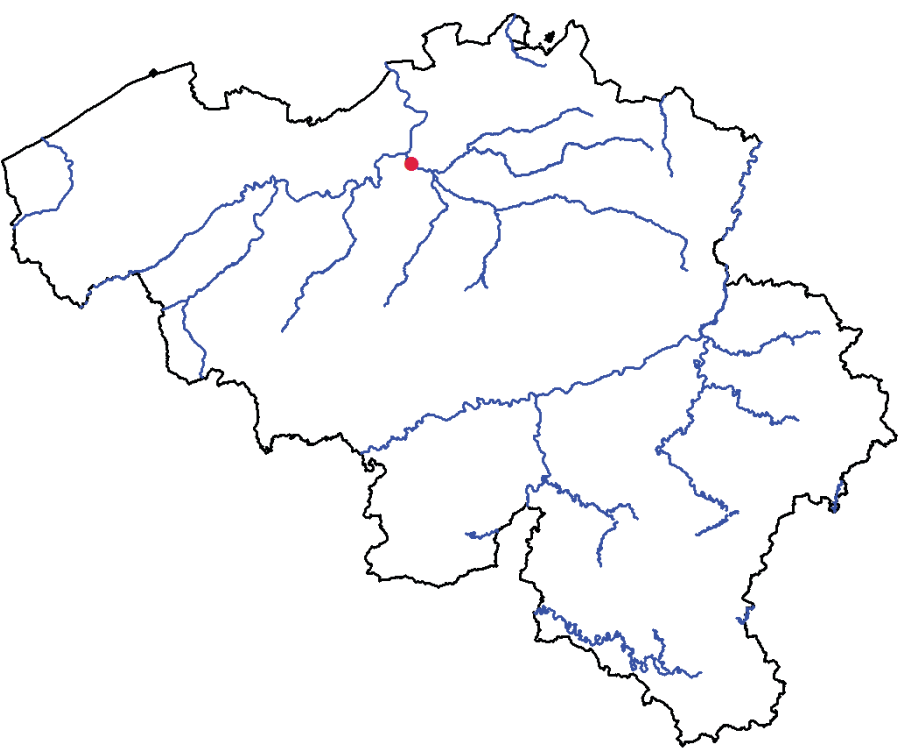

Figure 1 - Map of Belgium showing Niel (51.10138 N, 4.33747 E) marked with a red dot. 
mostly in coastal areas and lowlands. It can withstand long dry periods by retreating into the shell behind a calcareous epiphragm (2).

Ferussacia folliculum is native in the Western Mediterranean region (1), where its natural range extends from Portugal, Spain, the French Mediterranean coast (3), the Balearic Islands (4), Corsica $(5,6)$, Sardinia (7) Malta (8) and Sicily, to the South of continental Italy and Greece $(1,2)$. It is also present along the North African coast, from Morocco to Tunisia (9). The species has been recorded as a probable introduction in Madeira (10) and the Canary Islands (Tenerife, La Palma and Gran Canaria) (11). Outside Europe, the species has been introduced into North America (12), Australia (13-15), Réunion and Mauritius (16).

In continental Europe, a single historical (1879) sample has been reported from Parco Ciano, Lugano (Switzerland, Prealpine zone), which was attributed to an occasional introduction via imported Mediterranean plants (17). Yet, more recently, in 2014, the species was found in the 'Jardin botanique alpin du Lauterat' (département Les Hautes-Alpes, France), at an altitude of $2100 \mathrm{~m}$, so far the northernmost and highest-altitude recent record in Europe (9). During a new visit to this locality in summer 2016,

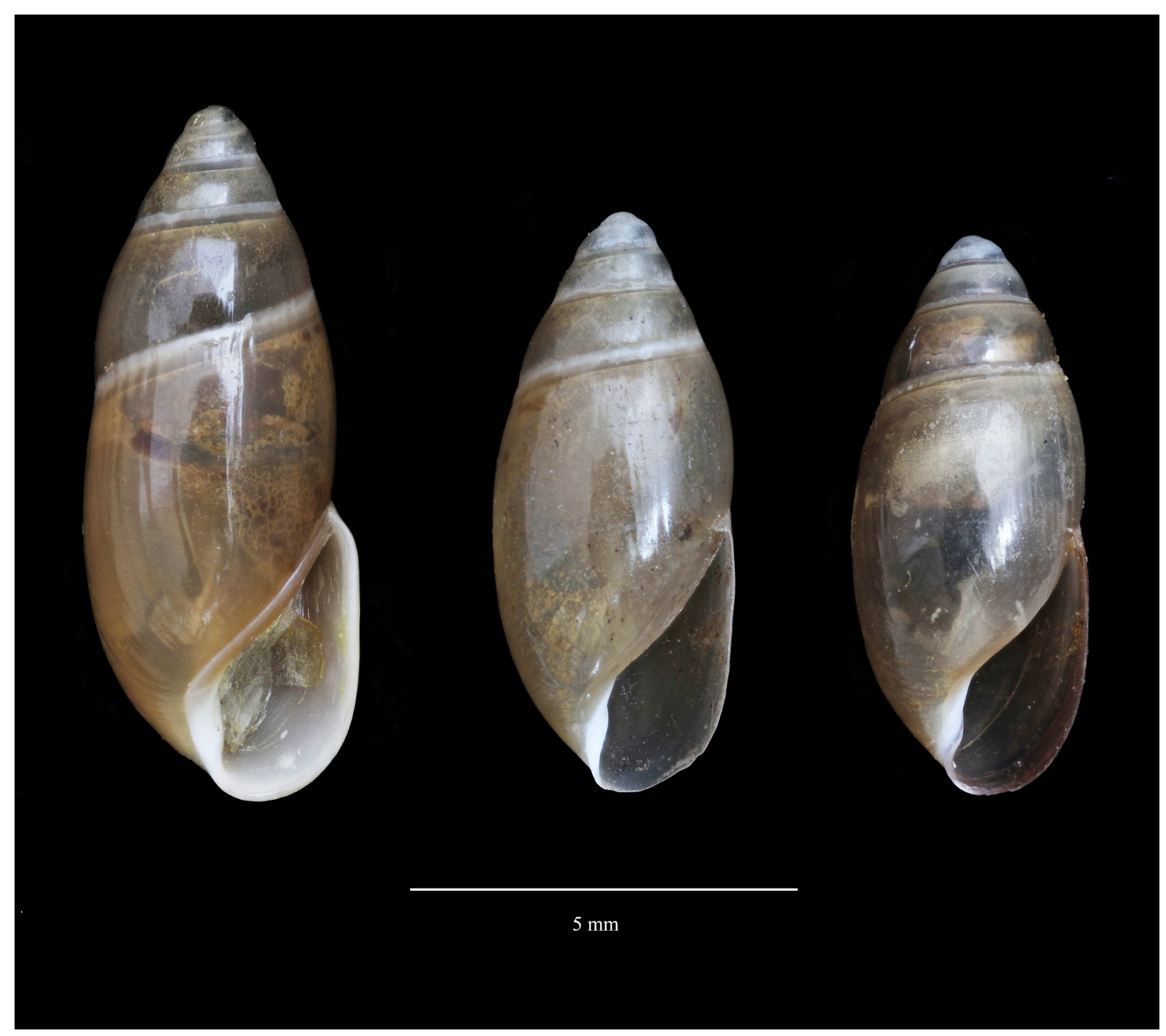

Figure 2 - Ferussacia folliculum. Left and middle: adult and subadult specimens from Malta, Malta, Hal-Ferh, Ghajn Tuffieћa (1983), coll. RBINS/Subcoll. Poppe, IG.28671, Nr. 177. Right: subadult specimen from Belgium, Niel, 2015, coll. RBINS (Project SPEEDY), IG.32643. 
again some live specimens were found (Christophe Perrier, 2016 pers. comm. 11 September). Hence it seems that the species has managed to survive at this site, i.e., further north and at higher altitudes than elsewhere in its natural European range.

On the $18^{\text {th }}$ of June 2015, while collecting landsnails in Niel, Belgium (51.10138 N, 4.33747 E) (Fig. 1), one living subadult specimen (Fig. 2) of Ferussacia folicullum was found in a litter sample. Since both shell and aperture are of nearly adult size, in view of the developing callus in the aperture, which is an adult characteristic, we assume it to be a subadult specimen.

The sampling site was an outdoor storage depot of pipes for construction works, adjacent to a wasteland and the nature reserve Walenbos. The litter sample was taken near the moist grassy border along the nature reserve. At about $20 \mathrm{~m}$ from the sampling spot, on the wasteland, there were remains of potted plants and a few piles of woodcuttings.

The shell (the animal was unfortunately lost) has been deposited in the collections of the Royal Belgian Institute of Natural Sciences under the collection catalogue number IG.32643 (coll. SPEEDY). On the $16^{\text {th }}$ of July 2016, we went back for another search for more specimens, but without success. Nevertheless, this is, to our knowledge, the first, and so far only, record of Ferussacia folliculum in Belgium (and adjacent regions). It may be the result of a one-time, unintentional introduction, probably via importation of plants or construction materials. Still, this sort of observation may be important as in the long term they may represent early warning data for future, more persistent, species introductions. Therefore, this record will be included in the list of alien species compiled and maintained by the European Alien Species Information Network (EASIN)(18).

\section{Acknowledgements}

We are indebted to "Lauwers J Plastics BVBA - Niel" for kindly giving us permission to take litter samples on their premises, to Yves Barette (RBINS) who took the pictures of Ferussacia folliculum, to Wouter Dekoninck (RBINS) for providing the map, and to Mathilde Delacoux (RBINS volunteer), who joined us and helped picking out samples. Very special thanks to Christophe Perrier for keeping us informed on the recent finds at the Lauterat site. This work was executed in the context of (1) IAP project SPEEDY financed by the Belgian Science Policy Office (BELSPO) and (2) the European Alien Species Information Network (EASIN: http://easin.jrc.ec.europa.eu/?AspxAutoDetectCookieSupport=1).

\section{References}

1. WeLteR- SCHUltes F. (2012). European non-marine molluscs, a guide for species identification. Planet Poster Editions, Göttingen.

2. WelteR- SChUltes F. (2013). Available from http://www.animalbase.uni-goettingen.de/zooweb/ servlet/AnimalBase/home/species?id=1615 [accessed 26 October 2013].

3. Kerney M.P. \& CAmeron R.A.D. (1999). Guide des escargots et limaces d'Europe. Delachaux \& Niestlé, Paris.

4. BECKMAN N.K. (2007). Die Land- und Süßwassermollusken der Balearischen Inseln. ConchBooks, Hackenheim.

5. HOLYOAK D.T. (1983). Distribution of land and freshwater Mollusca in Corsica (1983). Journal of Conchology 31: 235- 251.

6. FAlKner G., Ripken T.E.J. \& FALKNeR M. (2002). Mollusques continentaux de France. Liste de Référence annotée et Bibliographique. Collections Patrimoines Naturels 52, Muséum national d'Histoire naturelle, Paris. 
7. Manganelli G., Bodon M., FaVilli L. \& Guisti F. (1995). Gastropoda Pulmonata. In: Minelli A., RUfFo S. \& LA Posta S. (eds) Checklist delle specie della fauna italiana 16. Edizione Calderini. Bologna.

8. Cilia D.P., Sciberras A., SciberRas J. \& Pisani L. (2012). Terrestrial gastropods of the minor islets of the Maltese Archipelago (Mollusca Gastropoda). Biodiversity Journal 3: 543-554. Available from http://www.biodiversityjournal.com/pdf/3(4)_543-554.pdf [accessed 11 April 2017].

9. PERRIER C. (2014). Découverte de Ferussacia folliculum (Schröter, 1784) (Gastropoda, Ferussaciidae) dans le département des Hautes-Alpes, France. Folia Conchyliologica 26: 6-8. Available from http://www.cernuelle.com/download.php?lng=fr [accessed 24 May 2017].

10. SEDdon M. (2009). BIOTIR 2. The Landsnails of Madeira. An illustrated compendium of the landsnails and slugs of the Madeiran archipelago. BIOTIR Reports, Studies in Terrestrial and Freshwater Biodiversity and Systematics. National Museum of Wales, Cardiff.

11. NúÑEZ B.L. \& NúÑEZ F.J. (2010). Mollusca. In: AREChavaleta M., RodRÍGUEZ S., ZuRITA N. \& GARCíA A. (eds) Lista de especies silvestres de Canarias. Hongos, plantas y animales terrestres: 182-189 (2009). Gobierno de Canarias.

12. Robinson D.G. (1999). Alien invasions: the effects of the global economy on non-marine gastropod introductions into the United States. Malacologia 41: 413- 438.

13. Cotton B.C. (1954). A catalogue of introduced snails and slugs in Australia. Records of the South Australian Museum 11: 177- 187.

14. Venmans L.A.W.C. (1957). A species of Ferussacia in South Australia. Journal of the Malacological Society of Australia 1: 36- 44.

15. Sмiтн B.J. (1992). Zoological catalogue of Australia. Volume 8. Non-marine Mollusca. Australian Government Publishing Service, Canberra.

16. Griffiths O.L. \& Florens V.F.B. (2006). A Field Guide to the Non-Marine Molluscs of the Mascarene Islands (Mauritius, Rodrigues and Réunion) and the Northern Dependencies of Mauritius. Mauritius, Bioculture Press.

17. TuRner H., Kuiper J.G.J., Thew N., BernASCONI R., RËTSCHI J., WÜthrich M. \& GOSTElli M. (1998). Fauna Helvetica, 2. Atlas der Mollusken der Schweiz und Liechtensteins. CSCF/SEG, Neuchâtel.

18. Katsanevakis S., Bogucarskis K., Gatto F., Vandekerkhove J., Deriu I. \& Cardoso A.C. (2012). Building the European Alien Species Information Network (EASIN): a novel approach for the exploration of distributed alien species data. BioInvasions Records 1:235-245. Available from http://easin.jrc.ec.europa.eu/ [accessed 24 May 2017].

Manuscript received: 21 November 2016

Manuscript accepted: 5 April 2017

Published on: 27 July 2017

Branch editor: Isa Schön 